Discussion Paper No. 03-51

\title{
Local User-Producer
} Interaction in Innovation and Export Performance of Firms

Marian Beise and Christian Rammer

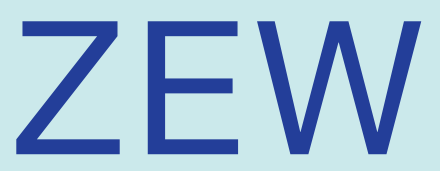

Zentrum für Europäische Wirtschaftsforschung GmbH

Centre for European

Economic Research 
Discussion Paper No. 03-51

\title{
Local User-Producer Interaction in Innovation and Export Performance of Firms
}

\author{
Marian Beise and Christian Rammer
}

Download this ZEW Discussion Paper from our ftp server:

ftp://ftp.zew.de/pub/zew-docs/dp/dp0351.pdf

Die Discussion Papers dienen einer möglichst schnellen Verbreitung von neueren Forschungsarbeiten des ZEW. Die Beiträge liegen in alleiniger Verantwortung der Autoren und stellen nicht notwendigerweise die Meinung des ZEW dar.

Discussion Papers are intended to make results of ZEW research promptly available to other economists in order to encourage discussion and suggestions for revisions. The authors are solely responsible for the contents which do not necessarily represent the opinion of the ZEW. 


\section{Non-technical Summary}

International differences in the export success of firms are traditionally explained by three advantages of the home country: low relative factor costs, a technological lead and a market advantage. While cost advantages correspond to the comparative advantage in trade theory and technological leads to local $\mathrm{R} \& \mathrm{D}$ and research activities, a demand side advantage is suggested by the homemarket theory. This theory asserts that companies develop new products that mainly fit demand conditions in their home market due to two reasons. First, firms have better information on local customer needs and consumer preferences. Second, even if firms perceive foreign needs, the corresponding product that fills it might not be fully conceived or may eventually not be adapted to unfamiliar conditions without additional costs. The export success of innovations driven by local demand depends on the degree to which locally demanded innovations meet international preferences or can be transferred to different environments.

In this paper we try to improve the analysis of the relationship between innovation and exports by including the distinction between innovations that are generated in response to idiosyncratic needs of the local market and innovations that are generated in response to local market conditions that trigger the international diffusion of those innovation. In analysing the export performance of firms that are predominantly developing innovations on demand of their customers we seek to identify the attributes of lead markets as distinct to idiosyncratically innovative markets.

Four characteristics of a domestic market are analysed with respect to their influence on the export performance of local innovations: Sophistication of demand, the level of competition, the degree of international orientation of customers, and similarity of domestic demand preferences to global preferences.

The basis of the empirical analysis is a general model of determinants of a firm's export activities. The propensity of a firm to export is a function of home market characteristics that affect the exportability of a firm's product and firm specific attributes. Among the firm specific attributes we distinguish between a firm's general exporting capabilities and innovation activities of the firm. In order to test the effect of user-producer interaction in innovation on export performance, we separate product innovators into two groups: those that reacted upon the demand for innovations by their customers in their home market, and those that used other sources of innovation. For the former we identify the characteristics of the market of their customers.

Data from the ZEW innovation survey are used to estimate the influence of home market characteristics on export success. The results do not fully support the claim that the domestic market has a large influence on the exportability of the innovations. It seems that the most important factor is still the effect of the 
volume of innovation. While not all innovations are exportable, the more a firm innovates the more innovations will be exported. Yet, some insights on market characteristics are derived as well. First, competition demand specialisation and international orientation of the firm's own product market stimulate export success. Second, export orientation of the customer industry has a strong, positive effect on the exports of a firm. Although intuitively clear, this result is not selfevident. It basically means that exporting customers demand components that are compatible with their export markets. Export performance therefore trickles down the value chain. 


\title{
Local User-Producer Interaction in Innovation and Export Performance of Firms
}

\author{
by \\ MARIAN Beise ${ }^{a b} \&$ Christian RAMmeR ${ }^{a}$ \\ ${ }^{a}$ Centre for European Economic Research (ZEW), Mannheim, Germany \\ ${ }^{b}$ Research Institute for Economics and Business Administration, Kobe \\ University, Kobe, Japan
}

August 2003

\begin{abstract}
There is ample evidence that user-producer interaction is an important factor for successful innovations. It is often claimed that user-producer interaction is most efficient in close proximity. On the other hand, innovations are a major determinant for the export performance of firms. Does this mean that intense local user-producer interaction always leads to exports? In contrast to this reasoning international marketing studies stress the problem of responsiveness to local preferences. In order to generate global innovation, an international firm should look for the global common denominator of national preferences. This paper investigates the question to what extend local demand is able to induce innovations that are export effective. We investigate data from the ZEW Innovation survey of 4,786 firms in the manufacturing and service industries. These firms were asked about the sources of their innovation and their exporting activities. We find evidence that the export orientation of the domestic market of innovators such as and the degree of competition stimulate export success. For multinational firms these results are important as well, because they can assess country markets in terms of the leverage effect of domestic demand and market conditions to generate global innovations.
\end{abstract}

Keywords: Export Performance, Innovation Activities, User Producer Interaction

JEL Classification: L80, C53, F14, O31

Acknowledgments: We would like to thank Dirk Czarnitzki for his valuable support in data processing and model estimation.

contact: Christian Rammer

ZEW, Centre for European Economic Research,

Department of Industrial Economics and International Management

P.O. Box 1034 43, D-68034 Mannheim, Germany

phone: +49-6 21-12 35-184 \& fax: +49-621 1235-170

e-mail: rammer@zew.de \& beise@zew.de 


\section{Introduction}

International differences in the export success of firms are traditionally explained by three advantages of the home country: low relative factor costs, a technological lead and a market advantage. These home country advantages can be used by local firms as a lever to enter foreign markets (Porter 1986, Krugman 1994). While cost advantages correspond to the comparative advantage in trade theory and technological leads result in (temporary) absolute trade advantages due to technological superiority of products, a demand side advantage is suggested by the home-market theory for explaining a competitive advantage of nations.

The home-market theory, which Linder (1961) originally introduced, asserts that companies develop new products that mainly fit demand conditions in their home market. There are two reasons for this. First, firms have better information on local customer needs and consumer preferences. ${ }^{1}$ These information asymmetries of local demand conditions are explained in innovation theory by the need of close contacts between producers, customers, suppliers and industrial serviceproviders in the introduction phase of innovations, and close contacts are facilitated by regional proximity and low cultural distance such as common language or common societal rules (e.g., Anderson et al. 1981, Fagerberg 1992). Second, even if firms perceive foreign needs, the corresponding product that fills it might not be fully conceived or may eventually not be adapted to unfamiliar conditions without additional costs (Linder 1961, p. 90). A lack of home testing ground causes heavy costs overseas, where the necessary information has to be found. Domestic firms will thus be more effective if they first react to changes in local demand and will get faster and better feedback from the first applications of their innovations which will have been introduced into the local market for refinement. This interactive learning process standardises innovations for widespread application.

A rich strand of literature in management science has pointed to the importance of innovation as an interactive process between users and producers. ${ }^{2}$ Various studies have found user-producer interaction to be a significant success factor for new products (among others, see Rothwell et al. 1974, Cooper and Kleinschmidt 1987, Gruner and Homburg 1997). In a different strand of literature it has been argued that the rate of innovations generated by a firm is positively correlated with its export success (Posner 1961, Vernon 1966). It is assumed in these models that the same innovations will be demanded everywhere and that there are no differences in preferences.

\footnotetext{
1The generation of economically valuable information through "on-the spot" informationexchanging interactions has been already stressed by Hayek (1945). The local market interaction discovers the knowledge dispersed over market participants.

${ }^{2}$ One of the fundamental articles is Lundvall (1988). Even earlier, Gemünden (1981) empirically studied different types and efficiencies of interaction processes between producers and customers in the computer industry.
} 
At first glance, it follows from both strands that close user-producer interaction in a country has a positive effect on the export performance of a country. However, this argumentation is inconsistent, because each strand makes different assumptions about the international variation of demand preferences. While user producer-interaction increases the domestic success of innovations, it would reduce export success if demand preferences vary internationally. The more an innovation design is adapted to the local environment, the less will be the costbenefit relation for users in other countries. Even improvements of innovations over time through customer feedback tend to focus on locally preferred attributes of the innovation and do not have to include attributes preferred abroad. If demand preferences are equal internationally, there would be no international difference for firms in the access to knowledge about market preferences.

The question of why users in foreign countries adopt innovations that have been developed in close interaction with users of other countries and are therefore adapted to their specific needs, has rarely been explicitly addressed. Fagerberg (1995, p. 244) admits that the positive effect of a high degree of interaction between users and producers on the international competitive position still lacks a theoretical explanation. Empirically, the relationship between user-producer interaction and the competitive advantage of nations is not clear, too. Empirical studies on the relationship between innovation activities and export of firms are mixed (for a review see Ebling and Janz 1999). Some authors find a positive correlation (Wakelin 1998, Sterlacchini 1999, Lefebvre et al. 1995, Smith et al. 2002, Roper and Love 2002) while some do not (Schlegelmilch and Crook 1988, Ito and Pucik 1993, Kumar and Siddharthan 1994). Overall, the relationship seems to depend on both the industry and the country of a firm. Studies on the relationship between users as source of innovation and exports are even more seldom. Lefebvre et al. (1998) test different R\&D related activities and strategies on exports and find a negative effect of collaborative $R \& D$ with customers on global exports. This confirms the argument that customers have country-specific preferences that ensue innovations that find less affection on foreign markets.

In this paper we try to improve the analysis of the relationship of innovation and exports by including the distinction between innovations that are generated in response to idiosyncratic needs and innovations that are generated in response to local market conditions that trigger the international diffusion of these innovations. In analysing the export performance of firms that are predominantly developing innovations on demand of particular customers or in response to a wide-ranging market request, we seek to identify the attributes of lead markets as distinct to idiosyncratically innovative markets. In Section 2 we discuss factors of local market conditions that should theoretically or that has been found in previous empirical studies to induce innovations, that can be exported. Section 3 presents our model and discusses the data source. Section 4 presents the result of the estimation and Section 5 concludes with some suggestions for future research. 


\section{Export Effectiveness of Local Markets}

In industries where demand shapes the rate and direction of technical change, a competitive advantage of a country results from the home market's characteristic to demand innovations that users in other countries will subsequently adopt as well. If demand preferences and the level of demand would be globally equal, then a competitive advantage is simply positively correlated with the innovativeness of local firms. The efforts of local firms to innovate can be the result of pressures to innovate or a higher willingness of local users to adopt an innovation. However, neither preferences no budgets are globally equal. In general, environmental conditions, traditions, tastes, and the purchasing power vary internationally so that different innovation designs will be preferred from country to country. In the case of varying demand preference, it must be theoretically explained why customers would prefer foreign products as opposed to domestic products, which would be expected to fit domestic needs much better. We suggest that the relationship between local market conditions and exports has to include the factors that make innovations not only successful in the home market but also abroad. Market conditions can be export effective and not export effective depending on their lead characteristic. We will next discuss some of the characteristics of a local market that can be expected to have an influence on the export performance of local innovations.

\section{$2.1 \quad$ Demand}

How can companies derive exports from domestic user-producer interaction in innovation if it can be assumed that local users will demand innovation designs that fit the local and not the global environment best? In the case of internationally equal demand preferences, a positive user-producer export relationship is likely if the opportunities or competency of firms and users to interact with each other vary from country to country. More efficient user-producer interaction is indeed suggested to explain differences in national competitiveness in the literature, e.g. in the case of waning industrial base of the United States (Dertouzos et al. 1989). In the pharmaceutical industry there are international differences in the efficiency of interaction between pharmaceutical producers and hospitals in the crucial phase of clinical testing (Reger et al. 1999). A better interaction leads to smoother approval processes, a shorter time-to-market and an export advantage. In the case of varying demand preferences, the efficiency of interaction is not sufficient for competitiveness. Linder (1961) as well as Vernon (1966) started to explain exports by a high per-capita-income of the home market. Countries with the highest per-capita income demand most innovations earlier than other countries, which follow when their per-capita-income increases. Today, however, although most industrialised countries have converged in terms of per capita income, differences in preferences prevail. Porter (1990) suggests that the quality of national demand has an effect on the international success of innovations. He finds that country demand for innovations can be idiosyncratic or anticipa- 
tory. Demand is idiosyncratic if users prefer innovation designs that will not be demanded in other countries, while countries with anticipatory demand prefer innovation designs which are subsequently demanded worldwide. Countries could be defined as idiosyncratically innovative if they adopt new ideas which no other country ever finds worthy of adopting. An overview of the international diffusion of specific innovations highlights the importance of the distinction between anticipatory and idiosyncratic innovativeness of a country (Beise 2002). The lead user concept by Eric v. Hippel (1988) offers another explanation for the diffusion of innovations. There are users that anticipate needs that other users will experience later. If there is a trend, users at the forefront of this trend demand innovation responding to this trend that will later be demanded by other users as well. This suggests that it is not the interaction itself that is the success factor, but the interaction with selected users, e.g. those that are at the forefront of an international trend.

\subsection{Competition}

The degree of competition is expected to be an important local market condition for the export performance of innovations. Competition between domestic companies and low market entry barriers for new companies increase the likelihood of the local market to identify unrevealed preferences and a valuable innovation design that appeals globally because of its technical superiority, practicability or superior cost-benefit relation. First of all, industrial customers tend to be more demanding towards their suppliers when they face competition than when they are tightly regulated or hold a monopoly (Porter 1990). The number of independent buyers, together with an early saturation of a market, create pressure for a reduction of prices and an improvement in product performance, thus giving buyers an incentive to replace an old product with the new version. Competition pushes costs down and makes a technology more price competitive against other innovation designs and the established technologies. For instance, intense competition amongst Japanese companies caused the cost of fax machines to reduce thirty-fold from 1980 to 1992 (Coopersmith 1993). Second, competition facilitates a market's anticipatory capacity. Fierce competition between local companies reveals information about buyers' needs earlier then less competitive markets. If preferences do not vary internationally, competitive markets are more likely to discover globally latent needs and select globally successful products which meet those needs best. Competitive markets are able to generate information about a buyer's needs because more alternatives can be tested and experience can be collected on a variety of product types. Even if preferences vary internationally, a competitive market can determine the globally dominant design because it might find a more superior design compared to non-competitive markets that takes international differences into consideration. In a competitive market, a company can turn any technological advantage into a market share taken from less creative rivals (Metcalfe 1995, p. 488). Because new products and technologies are frequently brought about by new companies (see e.g. Audretsch 1995), the 
absence of barriers to entry (Baumol et al. 1982) is essential for lead markets. The openness for new companies to enter the market makes the process more efficient in finding the design most profitable for the user by means of search and selection. Lead markets are therefore assumed to have a high degree of competition. Empirical evidence however is still more anecdotal, but in the case of Japan, Sakakibara and Porter (2001) find that the international success of innovations for which Japan is a lead market, such as fax machines, robots and cameras, is marked by fierce competition within the Japanese market, whereas governmental intervention and cartels are significantly associated with Japanese industries that are internationally less competitive.

\subsection{Multinational Firms}

Porter (1990) as well as Douglas and Wind (1987) note that preferences of a country for an innovation design can be actively transferred abroad, for instance by businessmen, the military and tourists. Mobile customers demand specific products and services wherever they travel despite the fact that different products or services might be more appropriate in different environments. The advantage they receive from using the same product or service is standardisation. Businessmen demand the same hotel service everywhere to avoid the inconvenience of adapting frequently to different local styles. Yet, the actors with the most powerful ability to transfer demand preferences worldwide are supposed to be multinational firms. Of course, the traditional theory would regard direct investments and exports as substitutes. Direct investment abroad could reduce exports by local manufacture facilities. Foreign affiliates are also established to develop innovation designs for the local market, lowering the export prospect of innovations at the headquarter. Yet, multinational companies have an economic incentive to use standardised equipment, software, protocols etc. in all of their global subsidiaries. Through cross-border consolidation of most industries, multinational firms are increasingly looking for global standardisation opportunities and synergies. For instance, Ford, GM, Renault and DaimlerChrysler are actively seeking components that can be used in all of their regional brands in their car and truck divisions in the US, Europe and Japan. The larger the standardisation advantages are, the more they compensate the advantages of locally responsive innovations abroad. Therefore, our hypotheses is that multinational firms enhance the export performance of a country. Specifically, we expect the country in which the headquarter of a multinational firm is located to gain most of the export enhancing effect since the headquarter has the highest leverage power of local innovations.

\subsection{Export Orientation}

It is also an important national advantage when companies are guided by local market participants or the local market context to increase the exportability of nationally preferred innovation designs. With knowledge about foreign market 
conditions, an innovator is able to design innovations to suit not only the local environment but to foreign environments as well through the incorporation of additional features. Three factors can deliver an export advantage: the similarity of local market conditions to foreign market conditions, domestic demand that is sensitive to the problems and needs of foreign countries, and local agents that put pressure on companies to develop exportable products. In the first place, innovations are easier to export if the environment and market conditions of foreign countries are similar to those of the domestic market the innovation was designed for. Dekimpe et al. (1998) support the hypothesis already suggested by Vernon (1979) that the higher the similarity of cultural, social and economic factors between two countries, the greater is the likelihood that an innovation design adopted by one of two countries will be adopted by the other country as well. A country is more likely to resort to a foreign design if the loss of benefit is small. Thus, the design most likely to become globally accepted is the one with specifics which are not very different from all other national demand specifics, i.e. the one which lies in the middle of the variety of national demand specifics, or with a minimal sum of differences from other countries' demand preferences. That gives a country whose innovation-specific attributes of the environment lie in the middle of the variety of environmental conditions an export advantage over countries with somewhat more extreme environmental conditions. With innovations that can be used in different environments, a company can catch up with foreign companies' innovations in their home countries at an early stage of the international competition between nation-specific technologies. International economies of scale and economies of adoption derived from the international usability allow the company with "dual-use" innovations to gain an advantage over companies focussed on their home markets.

\section{Econometric Model and Data}

\subsection{The Model}

The main aim of the empirical analysis is to test the the effect of a country's demand for an innovation on the ability of local firms to export this innovation, using data on German firms. We use the firm level of analysis because it allows us to capture industry specific attributes on a very fine disaggregation level as well as to control for firm specific attributes of export performance.

The basis of the empirical analysis is a general model of determinants of a firm's export activities as proposed in the empirical literature (see Bleaney et al. 2002, Roper and Love 2002, Aitken et al. 1997, Bernard and Jensen 1999, Wakelin 1998, Schlegelmilch and Crook 1988, Wagner 1996, Ebling and Janz 1999). Our full model suggests that the propensity of a firm to export is a function of market characteristics that affect the exportability of innovations developed by the firm as well as firm specific attributes. Among the firm specific attributes we distinguish between a firm's general exporting capabilities and innovation activities of the 
firm. The model may be written as follows:

$$
E_{i}=\alpha S_{i(j)}+\beta Z_{i}+\gamma I_{i(j k)}+u_{i}
$$

where $E_{i}$ is export performance of firm $i$ in industry $j, S$ is a vector for industry characteristics that have a direct effect on firm $i$ 's exports and $Z$ is a vector for firm characteristics that influence export performance but that have nothing to do with innovations. $I$ is a vector for a firm's innovation activities that are induced by characteristics of its own industry $j$ or the industry $k$ of its customers that demand a firms's innovation. $\alpha, \beta$ and $\gamma$ are parameters, and $u$ is an error term. In the following, we define the variables represented by the three vectors $S, Z$ and $I$.

The general industry attributes that are supposed to have a direct effect on exports are the tradability of products $T$ and the growth of demand GD. Tradability refers to the general export framework for firm $i$ 's products, such as tariff and non-tariff barriers to trade and trade impairing transaction costs etc. The growth of demand $(G D)$ for firm $i$ 's products in Germany controls for a likely crowding out of export activities due to a strong expansion of demand in the home market, or for export driving forces as a result of weak home market demand.

$$
S_{i(j)}=e\left(T_{i(j)}, G D_{i(j)}\right)
$$

The firm specific characteristics $Z$ that have a direct effect on exports included in the model are the size of the firm $S i z e_{i}$, its capital intensity $C I_{i}$, the skill level of employees $S k i l l_{i}$, cost efficiency denoted by unit labor costs $U L C_{i}$, whether it is an affiliate of a corporate group $G R_{i}$, its closeness to national borders $B D_{i}$ and whether it is located in East Germany $E A S T_{i}$. $Z_{i}$ is thus defined as a function $f$ with

$$
Z_{i}=f\left(\text { Size }_{i}, C I_{i}, S k i l l_{i}, U L C_{i}, G R_{i}, B D_{i}, E A S T_{i}\right)
$$

Size covers a firm's export advantages due to scale economies. Capital intensity and the skill level should reflect the specialisation of a firm on production factors with different comparative advantages for the German economy. We assume that high capital intensity and a high skill level represent a factor combination that provides comparative advantages in trade. Unit labour costs are viewed as a major determinant of price competitiveness on product markets. Being part of a corporate group rather than being an independent enterprise is used to capture the likely effects on exports that result from either a splitting up of regional markets within corporate structures (and thus curtailing export activities), or from improved access to foreign markets, especially in the case of intra-corporate specialisation by product markets among subsidiaries. On one hand, multinational firm establish foreign affiliates to serve the local market holding back exports. 
On the other hand, foreign direct investment is associated with improving market access and positively affect inter-firm trade (see Pfaffermayer, 1994, 1996; Pfaffermayer and Egger, 2003). The direction of the effect of this variable is thus not clear ex ante. The location of a firm may also affect its export behaviour. Physical distance to export markets is likely to increase transaction costs and thus product prices on export markets which may raise them to a level beyond competitiveness. Especially services are subject to trade-inhibiting transaction costs as services often require direct interaction between customers and firm employees at the customer's location. Service firms located close to a border may show higher export activities due to cross-border businesses. Firms from Eastern Germany may show a significantly different export behaviour, i.e. a lower export intensity. This may be attributed - despite structural effects such as small firm sizes and high unit labour costs - to the vanishing of their traditional export market in Eastern Europe since 1990, the short time period since 1990 to develop new export markets in OECD countries, possible negative reputation effects, and the missing of attractive cross-border markets for Eastern German service firms.

Special attention is paid to control for innovation activities of a firm to make sure that we do not confuse the direct effect of attributes of the local market on the exportability of innovations with a possible indirect effect via the volume of innovation output. Otherwise it could be argued that all innovations increase exports, and the market attributes would merely exert any direct effect on exports because they increase the output of innovations. A firm's innovative activities are captured in our model by four variables. The first is one characterising product innovators $P D_{i}$, the second one indicates whether the firm has introduced process innovations $P C_{i}$. The resources attributed to innovation are denoted by innovation intensity, i.e. the relation of innovation expenditures to turnover Inno $_{i}$. Finally, the "exclusivity" of innovation activities that may result in absolute competitive advantages in terms of (temporary) monopoly is broadly represented by the share of $\mathrm{R} \& \mathrm{D}$ expenditure in total innovation expenditure $R D_{i}$.

$$
I_{i(j k)}=g\left(P D_{i(j k)}, P C_{i}, \text { Inno }_{i}, R D_{i}\right)
$$

In order to test the effect of user-producer interaction in innovation on export performance, we differentiate the product innovators according to their interaction with the market. We distinguish firms that reacted upon the demand for innovations by single customers $P D C_{i}$ and by an (anonymous) market $P D M_{i}$. $P D n_{i}$ denotes firms that generate product innovations that were triggered by other factors such as scientific findings but not by significant market demand. Depending mostly on the product type but also on the targeted market, a firm can listen to the preferences of single important client or it can try to find out what the market wants by market research. If market research or a company's salespeople find that a market demands a specific new innovation, we would indicate this as market interaction. Interaction includes all kinds of market research that provide essential stimuli for new products or a significant adjustment of an 
innovation design. At that point we include the attributes of a market that are suggested to have an effect on the exportability of innovations, as outlined in Section 2. We distinguish the attributes of the own product market of a product innovating firm $i\left(P D-O_{i(j)}\right)$ and the attributes of the market of its customers $\left(P D-U_{i(k)}\right)$ from where firm $i$ has received impulses for product innovations. Thus, product innovations are defined as a function $h$ with

$$
P D_{i(j k)}=h\left(P D C_{i}, P D M_{i}, P D-O_{i(j)}, P D-U_{i(k)}, P D n_{i}\right)
$$

$P D-O$ and $P D-U$ capture the characteristics of the local market. In this model a firm's innovation activities are influenced by the charakteristics of industry $j$ a firm $i$ belongs to and of industry $k$ of the users of firm $i$ 's products that demand specific innovation designs. For example the innovations of a machinery manufacturer is shaped by the context of the machinery industry as well as the context of the customer industry such as the automobile industry. Several local market characteristics are tested whether they influence the exportability of innovations (see Section 2): the degree of competition $C P$, the presence of multinational firms $M N$ which could transfer innovations abroad, the sophistication of demand $S P$ and the export orientation of an industry $E X$. However, only the export orientation of the customer's industry can be tested because of an endogeneity problem. The endogenous variable (export orientation of firm $i$ ) interacts with the export orientation of $i$ 's industry $j$. In the case of the customer's industry, the effect of export orientation of the supplier on the export orientation of customers is small, so that we can include the export orientation of the customer industry as an exogenous variable. The attribute vectors are thus defined both for $i$ 's industry $j$ and the innovation triggering users' industry $k$ :

$$
\begin{aligned}
& P D-O_{i(j)}=p\left(O-S P_{i(j)}, O-C P_{i(j)}, O-M N_{i(j)}\right) \\
& P D-U_{i(k)}=q\left(U-S P_{i(k)}, U-C P_{i(k)}, U-M N_{i(k)}, U-E X_{i(k)}\right)
\end{aligned}
$$

\subsection{The Data Set}

To test the empirical model, we use data from the German innovation survey conducted by the ZEW. The ZEW innovation survey is an annual, representative firm survey conducted on behalf of the Federal Ministry of Education and Research. It is the German part of the Community Innovation Survey initiated by Eurostat. The ZEW innovation survey covers mining, manufacturing, energy and water supply, construction, wholesale and retail trade, transport services, banking and insurance, real estate and renting, telecommunication and software, R\&D services, producer-related services, and sewage and refuse disposal. It is based on a stratified random sample of all firms from these sectors with 5 or more employees.

In the questionnaire send to the companies in 1999, innovating firms were 
asked, among others, about the sources of their innovations, distinguishing customers, competitors, suppliers and research institutions. The exact wording of the question for customers is:

"Did you introduce new or significantly improved products or processes in the years 1996 to 1998 because certain clients or the market demanded them (eventually identified through market research)?"

Firms were asked to indicate both for "clients" and "general demand" whether such innovations occurred, and the share of sales with products that were triggered by clients or general demand, respectively. Furthermore, firms should name the industries of clients and general demand that provided these innovation impulses. The answers have been subsequently coded by NACE 3-digit-industries. Finally, firms were asked whether the customers came from Germany only, from abroad only, or from both Germany and abroad.

The questionnaire was sent to approx. 20,000 companies from manufacturing and the service sectors, of which 4,786 responded. A non-response analysis was carried out to control for distortions in response behaviour between innovation and non-innovating firms. The results of the non-response analyses showed, however, that there is no such distortion, neither concerning the share of innovating firms nor their innovation intensity. The firm sample can thus be regarded as representative for the sectors of the German economy covered by the survey with respect to innovation behaviour.

Among the respondents, the particular question on the sources of innovation was presented to companies that introduced at least one product innovation between 1996 and 1998, that is to 2,757 firms (58\%). Out of these, 1,798 firms (= $65 \%$ of all product innovators) stated that their innovations were responses to single customers or the market demand. On average, each firm with innovationrelated user-producer interaction named 1.82 different industries that initiated the firm's innovations. This means, that in total we derived 3,272 observations of industries triggering product innovations at suppliers.

A firm's export performance $E$ is measured as the ratio of exports to turnover for the reference year 1998. Exports include all sales outside Germany. For the service industries we used only the information whether the firm has export activities or not, since most of the firms do not export. Product and process innovators are defined as firms that have successfully introduced a new or significantly improved product $P D$, or a new or significantly improved process $P C$, in the preceding three year period (1996-1998). The definition of innovation follows the one given in the Oslo-Manual of OECD and Eurostat (see OECD and Eurostat 1997). Innovation expenditures comprise all current expenditures and investments for innovation projects for the reference year 1998. Innovation expenditures are related to turnover in 1998 (Inno). R\&D expenditures cover all 
intramural and extramural current expenditures and investments for research and development, following the definition for $\mathrm{R} \& \mathrm{D}$ as given in the Frascati-Manual by the OECD. They are included in the model as a share of total innovation expenditures $(R D)$ in the case of manufacturing firms. For service firms, we simply use a dummy for firms that carry out $R \& D$ continuously $(R D c)$ because the quality of the data on absolute figures of $R \& D$ expenditures is rather weak. The dummy variables on the innovation-related interaction with users take the value 1 if a firm uses clients ( $P D C)$ or (anonymous) demand $(P D M)$ as a source for product innovation. The dummy variable $P D n$ denotes product innovators that did not use clients or the general demand as the dominant source of innovation.

The market characteristics that are suggested to increase the exportability of innovations are derived from various data sources that were only available on different industry aggregation levels. In general, a higher level of industry class is assigned to each sub sectors of its industry class when disaggregated data was not available. Little data is available on competition in countries $(C P)$. As a proxy we us the price level in a sector compared to that in other countries. Intense competition on the home market normally results in low prices. Thus we expect that relatively low prices improve the exportability of innovations. In addition, low prices could also lead to a higher export orientation of companies seeking for profitable markets abroad. Data are taken from the OECD's purchasing power parities (PPP) statistics of 1996. There are more than 200 product groups that have been assigned to NACE 3-digit-level. In the case of more than one product group assigned to a sector, price levels were weighted using the absolute amount of demand for the respective product group. Relative prices for German sectors are calculated as the PPP for each sector divided by the PPP for the German economy as a whole. $C P$ is defined as the relative price level in a specific industry in the OECD divided by the price level in Germany. We expect therefore $C P$ to have a positive sign.

The industry specialisation on foreign direct investments $(M N)$ is used as a proxy for the capacity of a sector to transfer its innovations abroad through multinational firms. The variable is constructed as the relation of foreign direct investment by firms in a certain sector in Germany to the total domestic gross fixed investment of this sector in Germany, divided by the OECD average of this relation. The resulting variable $M N$ is a specialisation index that denotes a particular leverage effect of a German industry on the international market. Data on foreign direct investment for Germany by sectors are available from the German Federal Bank. Total gross fixed investment is available from the Federal Statistical Office. Data on foreign direct investment and gross fixed capital investment in OECD countries are taken from the UNCTAD Database and the STAN Database of the OECD. The index is measured for the average of the years 1997 and 1998 in order to avoid special effects in a single year.

Demand sophistication $S P$ is measured by an index of international demand 
specialisation of Germany per sector. International demand specialisation is a sector's share in total demand in Germany divided by a sector's average share in total demand in OECD countries. High values thus indicate a positive demand specialisation in Germany in a certain sector. Our argument is that a higher share of a particular sector in total demand of a country indicates that the market is more demanding in this sector, has a higher willingness to pay and invests more in evaluation and searching costs. Demand is defined as domestic production less exports plus imports. Data from OECD's STAN Database are used to calculate this index for the average of the years 1997 and 1998.

Export orientation $E X$ of an industry is measured by the share of exports in total turnover for each sector in Germany divided by the respective ratio for large OECD countries in 1998. This indicator thus measures the relative export performance of an industry in Germany compared to the average export intensity of this sector in the OECD. The STAN-Database is used to calculate the index for the average of the years 1997 and 1998. Small OECD countries are not considered as for some sectors in small countries, data seem to be inconsistent (exports clearly exceed total production).

Almost all product innovators with user interaction in innovation rely on domestic users. $43.9 \%$ of the firms that introduced user-driven innovations stated that these users solely came from Germany, another $55.3 \%$ stated that they came from both Germany and abroad, while only $0.8 \%$ interacted solely with users from abroad. The four variables on demand sector characteristics included in equation (5) were originally planned to be applied only when a firm indicates that innovations were initiated only by local customer industries or demanded by the local market. However, personal interviews with product managers from some of these firms that stated to have innovation triggering customers both from Germany and abroad showed that the vast majority of user-driven innovation impulses came from their home market, i.e. Germany. This means that the results of the estimation would be blurred if firms that indicated impulses from both Germany and abroad would be treated as distinguishable from those that answered to rely solely on domestic customers. We thus assume that the demand sectors $k$ mentioned by the firms as sources for their product innovations overwhelmingly refer to domestic demand.

Because most firms cited more than one demand sector for its innovation, firm observations were duplicated for each industry cited. In the econometric estimation process, each duplicated firm is weighted down by the number of duplications.

The ZEW innovation survey also provides information on firm characteristics that are represented in vector $Z$ in equation (1). Firm size is measured as the $\log$ of employees Size for the year 1998. We include the squared log of employees Size2 to control for a non-linear relationship. We use two variables to control 
for closeness to borders. The first variable indicates whether the firm is located in a district (Kreis) that borders a foreign country directly $B D$ and the second denotes firms in districts that boarders districts of the first type BD2. Fixed capital is measured as the stock of fixed assets at the end of 1998 and is related to the number of employees $(C I)$. In the case of service firms, data on fixed assets are not available for many firms so we had to use gross fixed investment instead (InvI). The share of graduates in total employment is a proxy for human capital intensity of production (Skill). The total number of graduates cover both graduates from universities and technical colleges ("Fachhochschulen"). Unit labor costs $(U C L)$ are measured as the ratio of total labor costs to value added for manufacturing firms, and as the ratio of total labor costs to turnover for service firms ( $U L C S$ ) because of difficulties to properly calculate value added in service firms.

Two sector specific variables shall control for export effects represented in vector $S$ in equation (1). Tradability $T$ is measured by the OECD countries' export ratio in the sector to which firm $i$ belongs to. Sector specific export ratios for the OECD countries in total are calculated from OECD's STAN Database for manufacturing sectors on the most disaggregated level available (partially 3-digit, partially 2-digit). For service sectors, such information is not available, however. Here we assign each sector according to its export orientation to non-exporting service sectors ( $T 1$ : retail trade, post and courier activities, real estate, local producer services such as industrial cleaning and provision of personnel, sewage and refuse disposal), service sectors with a low level of export activities (T2: construction, supporting transport services, banking and insurance, renting, software) and service sectors with a medium to high level of export activities (T3: wholesale trade, transport, telecommunication, knowledge-intensive producer services such as engineering services, $R \& D$ services, marketing and consulting). The growth of demand $(G D)$ in a certain sector in Germany is calculated by the change in the level of domestic demand, that is the volume of production less exports plus imports, between the average of the years 1991 to 1993 and the average of the years 1997 and 1998, using data from OECD's STAN Database.

Tables A1 and A2 in the Appendix list all variables used in the models and show descriptive statistics for the sample of manufacturing firms and the sample of service firms, respectively.

\section{Estimation Results}

The endogenous variable, the export performance, measured as the ratio of exports to sales, is zero for many firms. In the manufacturing sector, $28.4 \%$ of all firms in our sample are non-exporters, in the service sector, this ratio is even 72.3 $\%$. Given this data structure, the determinants of a firm's export performance is econometrically modelled using a Tobit-model for manufacturing firms. For 
service firms we only distinguish exporting from non-exporting firms, thus using a Probit model.

The latent part of the Tobit and the Probit model is given by

$$
E_{i}^{*}=\alpha S_{i}+\beta Z_{i}+\gamma I_{i}+u_{i}
$$

The observable part is given by

$$
E_{i}=\left\{\begin{array}{lll}
E_{i}^{*} & \text { if } \quad E_{i}^{*}>0 \\
0 & \text { if } \quad E_{i j}^{*} \leq 0
\end{array}\right.
$$

where the observed endogenous variable $E_{i}$ is censored from below at point $E_{i}^{*}=0$ in the Tobit Model, since a bulk of firms does not export at all. In the case of the Probit Model, equation (9) formally defines an exporter and a non-exporter. The Tobit and the Probit model are estimated with heteroscedasticity. It turned out that heteroscedasticity is produced only by industry affiliation, we thus use industry dummies for the heteroscedasticity term. Results of the heteroscedastic Tobit and heteroscedastic Probit Maximum Likelihood estimations are presented in the following tables 1 and 2 .

We estimated model (1) on different levels, always differentiating between manufacturing and servicefirms. The estimation starts with a model (A) that tests the general hypothesis that innovation activities of a firm increase its export success. In this simple model, without taking care of endogeneity of innovation activities (Ebling and Janz 1999, Smith et al. 2002), both input as well as output resources have significant positive effects on exports. On the input side, R\&D activities represent the source of international competitiveness. Innovation expenditures which include marketing activities, licence fees, etc., are not sufficient. On the output side, only product innovations are essential for exports, whereas process innovations even have a negative effect. Process innovations might be an indicator for price competition, where German companies are weak on average. As expected, export performance increases with firm size. Firms located in Eastern Germany have a smaller export share compared to their Western counterparts. Firms that are affiliates of a larger corporation seem to be more focussed on the domestic market. The indicators that control for tradability show the expected signs and are significant. An exception is growth of domestic demand in the service sector which exerts a negative effect on exports.

In the second estimation we include the effect of customers and demand for specific innovations (B). In general, both specific clients as well as the market as a whole have a positive effect on export performance. But the effect of the market is not significantly different from innovations that have been generated on the basis of other sources. Only single customers add to the export success of product innovators. 
Table 1: Estimation results for manufacturing firms ${ }^{a}$

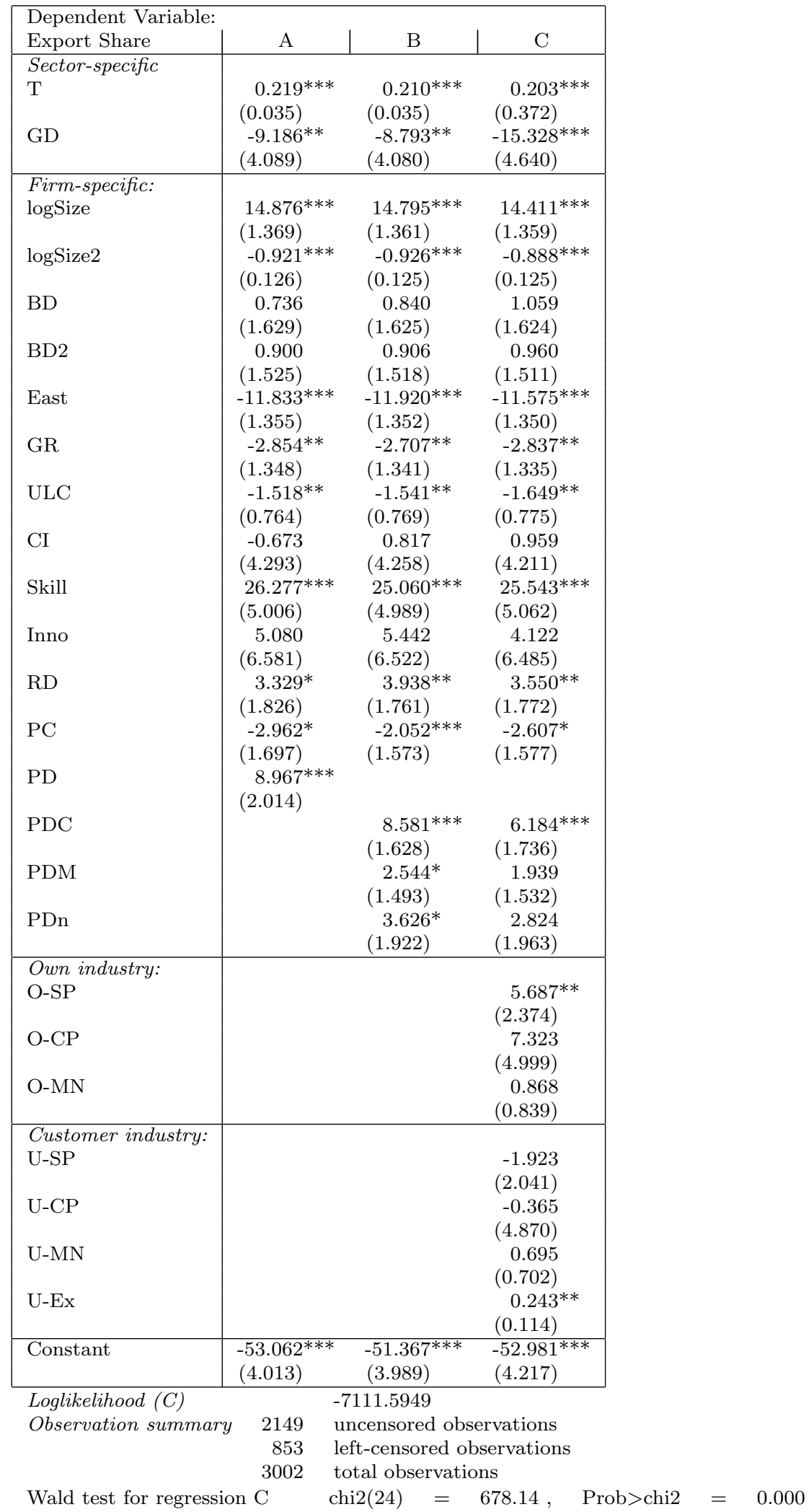

a) Tobit Estimations with heteroscedasticity, heteroscedasticity term includes 12 industry dummies. Standard errors in brackets. Coefficients with significance to the level of $99 \%(95 \%, 90 \%)$ are marked with $* * *(* *, *)$. 
Table 2: Estimation results for service firms ${ }^{a}$

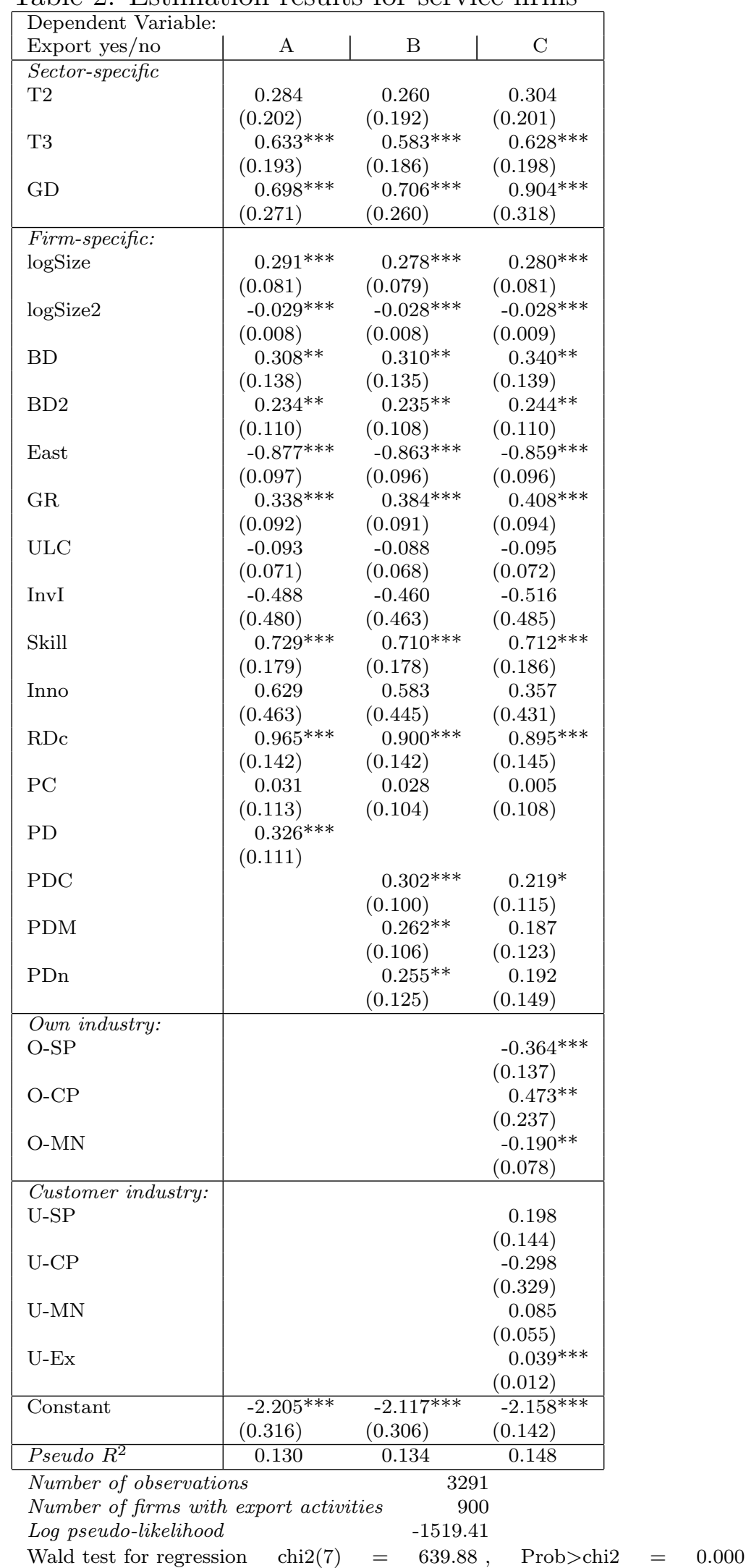

a) Probit Estimations with heteroscedasticity, heteroscedasticity term includes 7 industry dummies. Standard errors in brackets. Coefficients with significance to the level of $99 \%(95 \%, 90 \%)$ are marked with $* * *(* *, *)$. 
To further differentiate the market side effect on exports we include characteristics of the industry of a firm and the industry of its most influential customers in the estimation (C). With respect to the characteristics of the firm's own product market, the level of competition has a positive impact on export success in manufacturing and services, although the effect in manufacturing is hardly significant. Demand specialisation shows the expected positive sign in manufacturing while it is negative for services. The negative effect of multinational firm activity for sevice firms indicates that foreign direct investment in services may be a substitute to export activities which is plausible given high transaction costs for exports.

The results on the characteristics of the customers' industries suggest that not many of the indicators can significantly discriminate between lead customers that increase export performance and idiosyncratic customers that hinder exports. The most important result of the estimation is that the export orientation of customers increases the export success of suppliers. In the service sector, there is also but positive but rather weak effect of multinational firm activity. The insignificance of the other market side attributes could mean that they are irrelevant or - more likely in our opinion - that the variables used are not suitable as indicators for the market attributes that were intended to be tested. The price level - here used as an indicator for competition - might also be an indicator of the willingness to pay or the quality preferred in a country. In the latter case, a low price level may indicate export hampering characteristics of the users' demand. This could explain the insignificant influence on export performance. The insignificant effect of demand specialisation in the customers industry may be attributed to data problems. Exports of an industry could be overestimated due to the inclusion of components the manufacturing industry receives from other industry. Because demand is calculated as production minus export plus imports, an overestimation of exports leads to an underestimation of demand.

In the Appendix estimation results with customer industry dummies are shown (Table 3). They demonstrate which industries exert a positve or negative effect on exports of its suppliers. These results are only valid for Germany. The effects of markets are expected to be different from country to country. For instance while the metals industry (for manufacturing firms) and the mechanical engineering industry (for service firms) have a positive impact on the export success of its suppliers in Germany, in other countries this effect can be negative. Maybe surprisingly only some non R\&D-intensive industries can be singled out as having a significant export enhancing effect on other manufacturing firms such as textiles, basic metals and paper. Largely small specialised machinery manufacturers seemed to able to leverage the local demand and compensate their size disadvantage. For most service industries a negative sign is estimated (albeit not significant) and notably households have a negative effect on export activities of their suppliers, i.e. the german consumer goods industry. 


\section{Conclusions and further research}

Export success of industrialised countries depend on innovations. Many innovations are triggered or shaped by local customers and the local market preferences. Local markets play a vital role in a country's innovation success. Responsiveness to customers and market is seen as an important success factor of innovation. However, local preferences are not always in line, or not compatible with the world market. Local customers often demand specific innovation designs that are not demanded in foreign markets. Responding to idiosyncratic demand at home can hamper a firm's export strategy. Furthermore, despite an initial success in their countries, local designs are short lived. International standards often squeeze local innovation designs out of their home markets when scale economies of mass world market production emerge at their gates. In order to find measures for the degree of idiosyncracies of a local market and thus allow for a more differentiated assessment of local markets' ability to trigger global market innovations, we test several attributes of local markets that are supposed to strengthen (or weaken) the exportability of innovations of local firms.

The estimation results, however, do not fully support the claim that the domestic market has a large influence on the exportability of the innovations of local firms. Its seems that the most important factor is still the effect of the volume of innovation. This implies the following rule: While not all innovations are exportable, the more a firm innovates the more innovations will be exported. Yet, some insights on home market structures and on export success are derived as well. The export orientation of the customer industry has a strong, positive effect on the exports of a firm. Although intuitively, this result is not self-evident. First, characteristics of the innovator's industry such as degree of competion, growth of demand and international investments affect export performance. These results largely confirm other empirical results on market structure and export activities. Second exports have a direct export effect in that components are demanded in foreign markets as spare parts. Yet, a strong export orientation of the customer shapes its demand for supplier innovations. Exporting customers demand components that are compatible with their export markets. Export performance therefore trickle down the value chain. This demonstrates the interdependence of supplier-user relationships in international competitiveness.

The most important task for future research is to find better indicators for export-relevant characteristics of country markets such as competition, demand sophistication and demand preferences. The evaluation of the effect of competition terms especially important since most firms find markets with a high level of competitiveness and the prospect of low profits due to low prices unattractive. In fact, if the hypothesis is true, those markets would be especially attractive for innovation active firms as a test market and springboard to the world market. Looking at the industry structure in Germany and its international competitiveness, it becomes also clear that the model could be somehow overdeterminated 
and inappropriately specified. For instance Germany is obviously a prime market for motor vehicles that pressures local firms to meet high quality and technology standards. As a result, German car manufacturers became large multinational firms. Therefore the export effect of local demand leads over time to large and internationally competitive multinational companies and a specific industry specialisation of the country. Size, export orientation, foreign direct investments and innovation expenditures that are used in the model as exogenous variables are expected to increase with exports making a simultaneous model more suitable (Ebling and Janz 1999, Smith et al. 2002). The task is to refine the estimation model to match these specification problems. 


\section{References}

Aitken, B., G.H. Hanson, A.E. Harrison (1997): Spillovers, foreign investment, and export behaviour, Journal of International Economics 43: 103132 .

Anderson, E.S., B. Dalum, G. Villumsen (1981): International Specialisation and the Home Market - an empirical analysis, Industrial Development Research Series No. 19, Research Report, Aalborg University Press.

Audretsch, D.B. (1995): Innovation and Industry Evolution, Cambridge: The MIT Press.

Baumol, W.J., J.C. Panzar, R.D. Willig (1982): Contestable Markets and the Theory of Industry Structure, New York: Harcourt Brace Jovanovich.

Beise, M. (2002): Lead Markets: Harnessing local markets for global innovations, mimeo, Mannheim: Centre of European Economic Research.

Beise, M. (2001): Lead Markets: Country-Specific Success Factors of the global Diffusion of Innovations, Heidelberg: Physica.

Bernard, A.B., J.B. Jensen (1999): Exceptional exporter performance: cause, effect of both, Journal of International Economics 47: 1-25.

Bleaney, M., K. Wakelin (2002): Efficiency, innovation and exports, Oxford Bulletin of Economics and Statistics 64: 3-15.

Cooper, R.G., E.J. Kleinschmidt (1987): Success factors in product innovation, Industrial Marketing Management 16: 215-223.

Coopersmith, J. (1993): Facsimile's false starts, IEEE spectrum, February, 46-49.

Dekimpe, M.G., P.M. Parker, M. Sarvary (1998): "Globalisation": Modelling Technology adoption Timing across Countries, INSEAD working paper No. 98/69/MKT.

Dertouzos, M.L., R.K. Lester, R.M. Solow (1989): Made in America: Regaining the Productivity Edge, Cambridge, Mass.: MIT Press.

Douglas, S.P., Y. Wind (1987): The Myth of Globalisation, Columbia Journal of World Business 22, Winter: 19-29.

Ebling, G., N. Janz, (1999): Export and Innovation Activities in the German Service Sector: Empirical Evidence at the Firm Level, ZEW Discussion Paper No. 99-53, Mannheim. 
Fagerberg, J. (1992): The Home Market Hypothesis Re-examined: The Impact of Domestic User-Producer Interaction on Export Specialisation, in: B.-A. Lundvall (ed.), National Systems of Innovation, London, New York: Pinter, 226-239.

Fagerberg, J. (1995): User-Producer Interaction, Learning and Comparative Advantage, Cambridge Journal of Economics 19: 243-256.

Gemünden, H.G. (1981): Innovationsmarketing: Interaktionsbeziehungen zwischen Hersteller und Verwender innovativer Investitionsgüter, Tübingen: Mohr/Siebeck.

Gruner, K.E., C. Homburg (1997): Customer Interaction as a Key to New Product Success, mimeo, University of Vallendar.

Hayek, F.A. (1945): The Use of Knowledge in Society, American Economic Review 35: 519-530.

Hippel, E. v. (1988): Sources of Innovation, New York: Oxford University Press.

Ito, K., V. Pucik (1993): R\&D spending, domestic competition, and export performance of Japanese Manufacturing firms, Strategic Management Journal 14: $61-75$.

Krugman, P. (1994): Location and Competition: Notes on Economic Geography, in: R. Rumelt, D. Schendel, D. Teece (eds.), Fundamental Issues in Strategy: A Research Agenda, Boston: Harvard Business School Press, 463-493.

Kumar, N., N.S. Siddharthan (1994): Technology, firm size and export behaviour in developing countries: the case of Indian enterprises, Journal of Developing Studies 31: 289-309.

Lefebvre, É., L.A. Lefebvre, M. Bourgault (1998): R\&D-Related Capabilities as Determinants of Export Performance, Small Business Economics 10: $365-377$.

Lefebvre, L.A., É. Lefebvre, M. Bourgault (1995): Innovative Efforts as Determinants of Export Performance: The Case of Specialized Suppliers, Montréal: CIRANO-Centre interuniveristaire de recherche en analyse des organisations.

Linder, S. (1961): An Essay on Trade and Transformation, Uppsala.

Lundvall, B.-A. (1988): Innovation as an Interactive Process - from UserProducer Interaction to the National System of Innovation, in: G. Dosi et al. (eds.), Technical Change and Economic Theory, London: Pinter, 349-369. 
Metcalfe, S. (1995): The Economic Foundations of Technology Policy: Equilibrium and Evolutionary Perspectives, in: P. Stoneman (ed.), Handbook of the Economics of Innovation and Technical Change, Oxford: Blackwell, 409-512.

OECD (1994): Frascati Manual. The Measurement of Scientific and Technological Activities, Paris

OECD, Eurostat (1997): Oslo Manual. Proposed Guidelines for Collecting and Interpreting Technological Innovation Data, Paris.

Pfaffermayer, M. (1994): Foreign Direct investment and Exports: A Time Series Approach, Applied Economics 26: 337-351.

Pfaffermayer, M. (1996): Foreign Outward Direct Investment and Exports in Austrian Manufacturing: Substitutes or Complements?, Weltwirtschaftliches Archiv 132: 501-522.

Pfaffermayer, M., P. Egger (2003): Distance, Trade and FDI: A SUR HausmanTaylor Approach, Journal of Applied Econometrics (forthcoming).

Porter, M.E. (1986): Changing Patterns of International Competition, California Management Review 28: 9-40.

Porter, M.E. (1990): The Competitive Advantage of Nations, New York: Free Press.

Posner, M.V. (1961): International Trade and Technical Change, Oxford Economic Papers 30: 323-341.

Reger, G., M. Beise, H. Belitz (1999): Innovationsstandorte multinationaler Unternehmen: Internationalisierung technologischer Kompetenzen in der Pharmazie, der Halbleiter- und Telekommunikationstechnik, Schriftenreihe des FhG-ISI, Band 37, Heidelberg: Physica.

Roper, S., J.H. Love (2002): Innovation and Export Performance: Evidence from UK and German Manufacturing Plants, Research Policy 32: 10871102.

Rothwell, R., C. Freeman, A. Horseley, V.T.P. Jervis, J. Townsend (1974): Sappho Updated - Project Sappho Phase II, Research Policy 3: 204-225.

Sakakibara, M., M.E. Porter (2001): Competing at home to win abroad: Evidence from Japanese Industry, Review of Economics and Statistics 83(2): $310-322$.

Schlegelmilch, B., J.N. Crook (1988): Firm-level Determinants of Export Intensity, Managerial and Decision Economics 9: 291-300. 
Smith, V., E.S. Madsen, M. Dilling-Hansen (2002): Export Performance and Investment in RED, Aarhus: The Danish Institute for Studies in Research and Research Policy.

Sterlacchini, A. (1999): Do innovative activities matter to small firms in nonR\&D-intensive industries? An application to export performance, Research Policy 28: 819-832.

Vernon, R. (1966): International Investment and International Trade in the Product Cycle, Quarterly Review of Economics 88: 190-207.

Vernon, R. (1979): The Product Cycle Hypothesis in a New International Environment, Oxford Bulletin of Economics and Statistics 41 (4):, 255-267.

Wagner, J. (1996): Export performance, human capital, and product innovation in Germany: a micro view, Jahrbuch für Wirtschaftswissenschaften 47: $40-45$.

Wakelin, K. (1998): Innovation and export behaviour at the firm level, Research Policy 26: 829-841. 


\section{Appendix}

Table A1: Descriptive statistics for manufacturing firms

\begin{tabular}{|l|rrrr|}
\hline Expshare & Mean & Std. Dev. & Min & Max \\
\hline T & 48.314 & 22.120 & 11.704 & 144.971 \\
GD & -0.379 & 0.164 & -0.838 & 0.526 \\
logSize & 4.648 & 1.774 & 0 & 12.144 \\
logSize2 & 24.758 & 18.974 & 0 & 147.483 \\
BD & & & 0 & 1 \\
BD2 & & & 0 & 1 \\
East & 0.289 & & 0 & 1 \\
GR & 0.375 & & 0 & 1 \\
ULC & 0.561 & 0.599 & -20 & 6.855 \\
CI & 0.191 & 5.599 & 0 & 306.782 \\
Skill & 0.108 & 0.138 & 0 & 1 \\
Inno & 0.048 & 0.096 & 0 & 1.322 \\
RD & 0.461 & 0.402 & 0 & 1 \\
PC & 0.696 & & 0 & 1 \\
PD & 0.755 & & 0 & 1 \\
PDC & 0.504 & & 0 & 1 \\
PDM & 0.378 & & 0 & 1 \\
PDn & 0.132 & & 0 & 1 \\
O-SP & 0.123 & 0.389 & -0.702 & 1.785 \\
O-CP & 0.044 & 0.116 & -0.339 & 0.451 \\
O-MN & 0.517 & 0.967 & -2.249 & 2.529 \\
U-SP & 0.067 & 0.337 & -0.702 & 1.855 \\
U-CP & 0.049 & 0.144 & -0.825 & 0.451 \\
U-MN & 0.105 & 1.164 & -3.335 & 2.529 \\
U-Ex & 4.351 & 7.590 & -7.481 & 31.223 \\
\hline
\end{tabular}

Table A2: Descriptive statistics for service firms

\begin{tabular}{|l|rrrr|}
\hline Expshare & Mean & Std. Dev. & Min & Max \\
\hline T2 & 0.381 & & 0 & 1 \\
T3 & 0.328 & & 0 & 1 \\
GD & -0.269 & 0.288 & -1.025 & 0.676 \\
logSize & 4.052 & 1.867 & 0 & 12.133 \\
logSize2 & 19.910 & 17.783 & 0 & 147.221 \\
BD & 0.107 & & 0 & 1 \\
BD2 & 0.165 & & 0 & 1 \\
East & 0.379 & & 0 & 1 \\
GR & 0.355 & & 0 & 1 \\
ULC & 0.362 & 0.581 & 0 & 15.563 \\
InvI & 0.033 & 0.120 & 0 & 1.905 \\
Skill & 0.193 & 0.249 & 0 & 1 \\
Inno & 0.033 & 0.114 & 0 & 2.709 \\
RDc & 0.130 & 0.336 & 0 & 1 \\
PC & 0.561 & 0.774 & 0 & 1 \\
PD & 0.557 & 0.496 & 0 & 1 \\
PDC & 0.290 & & 0 & 1 \\
PDM & 0.293 & & 0 & 1 \\
PDn & 0.131 & & 0 & 1 \\
O-SP & 0.241 & 0.606 & -1.177 & 1.855 \\
O-CP & 0.077 & 0.227 & -0.825 & 0.440 \\
O-MN & -0.709 & 1.121 & -3.104 & 1.168 \\
U-SP & 0.011 & 0.288 & -1.177 & 1.855 \\
U-CP & 0.039 & 0.135 & -0.825 & 0.440 \\
U-MN & -0.141 & 0.948 & -3.335 & 2.529 \\
U-Ex & 1.582 & 4.775 & -7.481 & 31.223 \\
\hline
\end{tabular}


Table A3: Estimation of export activity of firms with customer industry dummies

\begin{tabular}{|c|c|c|c|c|}
\hline & \multicolumn{2}{|c|}{ Manufacturing: Tobit Regressions } & \multicolumn{2}{|c|}{ Services: Probit Regressions } \\
\hline & Coefficient & $\begin{array}{l}\text { No. of times } \\
\text { industry named }\end{array}$ & Coefficient & $\begin{array}{l}\text { No. of times } \\
\text { industry named }\end{array}$ \\
\hline Agriculture & $\begin{array}{r}-12.623 \\
(10.800)\end{array}$ & 10 & $\begin{array}{l}-3.339^{* *} \\
(1.324)\end{array}$ & 15 \\
\hline Mining & $\begin{array}{r}2.859 \\
(18.601)\end{array}$ & 4 & $\begin{array}{l}3.288^{* * *} \\
(1.106)\end{array}$ & 4 \\
\hline Food beverages \& tobacco & $\begin{array}{r}0.906 \\
(5.366)\end{array}$ & 44 & $\begin{array}{r}0.856 \\
(0.546)\end{array}$ & 18 \\
\hline Textiles & $\begin{array}{l}27.155^{* * *} \\
(7.178)\end{array}$ & 18 & $\mathrm{a}$ & 5 \\
\hline Apparel; leather & $\begin{array}{l}19.616^{* *} \\
(8.959)\end{array}$ & 11 & a & 5 \\
\hline Wood \& wood products & $\begin{array}{r}3.074 \\
(10.172)\end{array}$ & 12 & $\begin{array}{r}2.385 \\
(1.863)\end{array}$ & 4 \\
\hline Paper \& paper products & $\begin{array}{l}27.579^{* * *} \\
(9.797)\end{array}$ & 10 & $\begin{array}{l}4.194^{* * *} \\
(1.373)\end{array}$ & 7 \\
\hline Publishing, printing & $\begin{array}{r}8.085 \\
(7.915)\end{array}$ & 22 & $\begin{array}{r}0.553 \\
(0.661)\end{array}$ & 10 \\
\hline Chemicals \& petroleum & $\begin{array}{r}4.204 \\
(4.641)\end{array}$ & 77 & $\begin{array}{l}1.012^{* * *} \\
(0.336)\end{array}$ & 45 \\
\hline Pharmaceuticals & $\begin{array}{l}13.169^{*} \\
(6.832)\end{array}$ & 27 & $\begin{array}{r}0.169 \\
(0.503)\end{array}$ & 17 \\
\hline Rubber \& plastic products & $\begin{array}{l}11.986^{*} \\
(6.749)\end{array}$ & 31 & $\begin{array}{r}0.587 \\
(0.863)\end{array}$ & 6 \\
\hline Other non-metallic mineral products & $\begin{array}{l}10.159 \\
(8.207)\end{array}$ & 18 & $\begin{array}{l}1.235^{* *} \\
(0.574)\end{array}$ & 14 \\
\hline Basic metals & $\begin{array}{l}30.980^{* * *} \\
(10.244)\end{array}$ & 14 & $\begin{array}{l}1.596^{* *} \\
(0.674)\end{array}$ & 12 \\
\hline Fabricated metal products & $\begin{array}{l}9.845^{*} \\
(5.735)\end{array}$ & 51 & $\begin{array}{l}1.758^{* * *} \\
(0.582)\end{array}$ & 17 \\
\hline Machinery \& equipment n.e.c & $\begin{array}{r}3.086 \\
(3.095)\end{array}$ & 241 & $\begin{array}{l}0.817^{* *} \\
(0.325)\end{array}$ & 65 \\
\hline Office \& computing machinery & $\begin{array}{r}-9.280 \\
(16.151)\end{array}$ & 6 & $\begin{array}{r}-0.981 \\
(0.900)\end{array}$ & 6 \\
\hline Electrical machinery & $\begin{array}{r}6.203 \\
(4.910)\end{array}$ & 68 & $\begin{array}{r}0.538 \\
(0.584)\end{array}$ & 13 \\
\hline Radio, TV, communication equipment & $\begin{array}{l}11.729^{* *} \\
(5.917)\end{array}$ & 34 & $\begin{array}{l}2.622^{* * *} \\
(0.984)\end{array}$ & 7 \\
\hline Medical, precision \& optical instruments & $\begin{array}{r}1.259 \\
(5.930)\end{array}$ & 46 & $\begin{array}{r}1.033 \\
(0.643)\end{array}$ & 15 \\
\hline Motor vehicles \& trailers & $\begin{array}{l}-2.282 \\
(2.887)\end{array}$ & 216 & $\begin{array}{l}0.542^{*} \\
(0.330)\end{array}$ & 62 \\
\hline Other transport equipment & $\begin{array}{r}9.009 \\
(5.682)\end{array}$ & 42 & $\begin{array}{r}0.860 \\
(0.642)\end{array}$ & 8 \\
\hline Furniture; manufacturing n.e.c & $\begin{array}{r}2.825 \\
(7.178)\end{array}$ & 26 & $\begin{array}{r}-1.123 \\
(0.817)\end{array}$ & 8 \\
\hline Recycling \& sewage, refuse disposal & $\begin{array}{r}-7.097 \\
(13.443)\end{array}$ & 8 & $\begin{array}{r}0.769 \\
(0.492)\end{array}$ & 12 \\
\hline Electricity, gas \& water supply & $\begin{array}{r}-7.477 \\
(7.083)\end{array}$ & 24 & $\begin{array}{r}-0.235 \\
(0.558)\end{array}$ & 15 \\
\hline Construction & $\begin{array}{r}-0.940 \\
(4.376)\end{array}$ & 77 & $\begin{array}{r}0.024 \\
(0.305)\end{array}$ & 67 \\
\hline Sale \& repair of motor vehicles; fuel sale & $\begin{array}{r}-2.138 \\
(11.863)\end{array}$ & 9 & $\begin{array}{l}-0.502 \\
(0.595)\end{array}$ & 7 \\
\hline Wholesale trade & $\begin{array}{r}3.954 \\
(3.990)\end{array}$ & 96 & $\begin{array}{r}0.348 \\
(0.392)\end{array}$ & 44 \\
\hline Retail trade; repair & $\begin{array}{r}1.871 \\
(3.299)\end{array}$ & 129 & $\begin{array}{r}0.144 \\
(0.293)\end{array}$ & 83 \\
\hline Hotels and restaurants & $\begin{array}{r}-17.930 \\
(11.936)\end{array}$ & 10 & $\begin{array}{l}-0.046 \\
(0.681)\end{array}$ & 11 \\
\hline Transport by land, air \& water; pipelines & $\begin{array}{r}0.600 \\
(5.477)\end{array}$ & 48 & $\begin{array}{r}0.192 \\
(0.373)\end{array}$ & 61 \\
\hline Post \& telecommunications & $\begin{array}{r}-13.224 \\
(9.533)\end{array}$ & 21 & $\begin{array}{c}-0.015 \\
(0.559)\end{array}$ & 16 \\
\hline Financial intermediation & $\begin{array}{r}-8.948 \\
(8.565)\end{array}$ & 27 & $\begin{array}{r}0.463 \\
(0.291)\end{array}$ & 92 \\
\hline Real estate \& renting & $\begin{array}{r}-20.004 \\
(15.896)\end{array}$ & 9 & $\begin{array}{r}-0.098 \\
(0.426)\end{array}$ & 31 \\
\hline Computer services & $\begin{array}{r}-2.502 \\
(13.323)\end{array}$ & 7 & $\begin{array}{r}-0.193 \\
(0.605)\end{array}$ & 18 \\
\hline Research and development & $\begin{array}{r}-4.734 \\
(7.874)\end{array}$ & 25 & $\begin{array}{r}0.316 \\
(0.579)\end{array}$ & 6 \\
\hline Other business activities & $\begin{array}{r}-5.827 \\
(7.370)\end{array}$ & 30 & $\begin{array}{r}-0.155 \\
(0.343)\end{array}$ & 37 \\
\hline Public administration \& defence & $\begin{array}{r}-7.711 \\
(5.270)\end{array}$ & 61 & $\begin{array}{c}-0.211 \\
(0.226)\end{array}$ & 130 \\
\hline Education & $\begin{array}{r}-2.975 \\
(15.095)\end{array}$ & 7 & $\begin{array}{r}0.245 \\
(0.921)\end{array}$ & 6 \\
\hline Health and social work & $\begin{array}{r}-4.293 \\
(5.380)\end{array}$ & 52 & $\begin{array}{l}-0.829^{* * *} \\
(0.393)\end{array}$ & 38 \\
\hline Recreational, cultural, sporting activities & $\begin{array}{r}-7.062 \\
(11.133)\end{array}$ & 13 & $\begin{array}{r}0.356 \\
(0.573)\end{array}$ & 17 \\
\hline Private households & $\begin{array}{l}-10.967^{* *} \\
(4.957)\end{array}$ & 61 & $\begin{array}{l}-0.814^{* * *} \\
(0.271)\end{array}$ & 188 \\
\hline Constant & $\begin{array}{l}-51.444^{* * *} \\
(4.169)\end{array}$ & Total: 1742 & $\begin{array}{l}-2.387^{* * *} \\
(0.367)\end{array}$ & Total: 1242 \\
\hline
\end{tabular}

